\title{
The Views and Opinions of School Principals and Teachers on Positive Education*
}

\author{
Aslı Uz Baş ${ }^{1}$, Necla Şahin Fırat ${ }^{1}$ \\ ${ }^{1}$ Buca Faculty of Education, Dokuz Eylül University, Izmir, Turkey \\ Correspondence: Aslı Uz Baş, Buca Faculty of Education, Dokuz Eylül University, Izmir, 35150, Turkey.
}

Received: December 20, 2016

Accepted: December 30, 2016

Online Published: January 4, 2017

doi:10.11114/jets.v5i2.1996

URL: http://dx.doi.org/10.11114/jets.v5i2.1996

*This study is presented at the 1st Eurasian Congress on Positive Psychology, Istanbul, Turkey, April 2016.

\begin{abstract}
The purpose of this study is to assess the views and opinions of school principals and teachers on positive education. The sample of the study includes 8 school principals and 12 teachers who attend different public schools in İzmir, Turkey. Data is collected through semi-structured interview technique. Findings show that majority of the participants have no knowledge about positive education and positive psychology. Participants state that schools can increase students' well-being, and both academic and well-being skills can be taught at schools. Finally, majority of the participants report that positive education is necessary for Turkish schools.
\end{abstract}

Keywords: positive education; school principals; teachers; views; opinions

\section{Introduction}

Positive education aims to teach both the skills of well-being and the skills of academic achievement (Seligman et al., 2009). Green (2014) defines positive education as "the application of well-being science into an educational setting aimed at increasing the resilience and well-being of students, staff, and whole-school community". Positive psychology is the study of the conditions and processes that contribute to optimal flourishing in individuals, groups and organisations (Gable \& Haidt, 2005). The major goal of positive education is to promote flourishing or positive mental health within the school community (Norrish, Williams, O'Connor, \& Robinson, 2013).

Schools play a critical role in promoting well-being of children and adolescents (Dulagil, Green, \& Ahern, 2016). Research findings reveal that school climate is associated with student well-being and mental health outcomes. Schools tend to overemphasize academic achievement and focus on identifiying and remediating students' weaknesses. However, positive psychology focuses on the unique positive characteristics of the individual and maximizes his/her potential (Terjesen, Jacofsky, Froh \& Digiuseppe, 2004). Csikszentmihalyi (2009), one of the pioneers of positive psychology, claim that "We have to find ways to make it enjoyable to develop one's consciousness, instead of filling the mind with passive and vicarious activities which do not build skills, character or cooperation." According to Seligman et al. (2009), there are three reasons for teaching well-being at schools: First of all, positive education programs delivered in school are proven to prevent depression. Second, positive education programs are well-documented to improve young perople's happiness. The third reason is that more well-being is associated with more learning.

Association between well-being and academic achievement takes its source from Fredrickson's (2004) broaden and build theory. The theory postulates that positive emotions broaden an individual's momentary thought-action repertoire, and can build that individual's enduring personal resources. Initial research findings support the broaden and build theory and the role of positive emotions in students' engagement at school and with learning (Reschly, Huebner, Appleton \& Antaramian, 2008).

Recently, several studies have been designed to incorporate positive psychology into schools in different countries. These programmes have targeted to improve children's and adolescents' subjective well-being. The first empirical study of a Positive Psychology Curriculum for adolescents is the Strath Haven Positive Psychology Curriculum. The major goals of the programme have been to help students identify their signature character strengths, and to increase students' use of these strengths in daily life. A total of 347 year 9 students have been included in the study. The curriculum has consisted of approximately 20-25 80-minute sessions have delivered over the year. Findings have revealed that the 
positive psychology programme have increased students' reports of enjoyment and engagement in school, and have improved social skills such as empathy, cooperation, assertiveness, self-control according to both mothers' and teachers' reports (Seligman et al., 2009).

An example of the implementation of Positive Education in schools is the Geelong Grammar School Project. Geelong Grammar School is one of Australia's great schools in Victoria. The school has invited a team of senior positive psychology researchers (e.g., Martin Seligman, Barbara Fredrickson) in 2008 to teach basic theoretical elements and skills of positive psychology to school staff. After the training period, the professional teachers have embedded positive education elements into most academic courses in several grades. Findings have revealed that the programme have improved conflict resolution skills between students, have led to emerge a common strengths-based language shared by students and staff, and have increased levels of individual flourishing among 7th year students (Williams, 2011).

Another school-based positive psychology intervention for school-aged children is Maytiv School Program in Israel. The entire student population and educational staff of this large middle school in the center of Israel have been included in the programme. The researchers have employed a 2-year longitudinal repeated measures design in order to determine the effects of the programme. The major goal of the programme has been to promote adolescents' mental-health and well-being. The findings have showed significant decreases in general distress, anxiety and depression symptoms among the intervention participants. Participants have also showed significant increases in self-esteem, self-efficacy and optimism, and reduced interpersonal sensitivity symptoms (Shoshani \& Sarit Steinmetz, 2013).

In more recent years, Noble and McGrath (2015) have developed an organising tool for the implementation of Positive Education. The authors have chosen the term PROSPER for defining this new framework. The PROSPER acronym represents Positivity, Relationships, Outcomes, Strengths, Purpose, Engagement, and Resilience. PROSPER focuses on the application of Positive Psychology research to educational contexts. The researchers have also conducted a study in order to get opinions of educators on the usefulness of the PROSPER framework. The data has been obtained through surveys conducted with researchers from the Institute of Positive Psychology and Education and fifty-four educators including teachers and principals from four different schools. Findings have showed that all respondents agreed that the PROSPER framework would have helped to provide a common language about well-being within the schools.

The findings of above mentioned studies support for the effectiveness of school-based positive psychology programs. In Turkey, while there has been increasing recognizing of the field of positive psychology, no previous studies have been conducted on the implemention of positive psychology in the schools. There are only a few studies addresses positive psychology interventions among university students. Koydemir and Kahraman (2015) have reported that the "Happiness and Well-Being Seminar" course which handles positive psychology subjects caused increased scores of life satisfaction, life engagement, and hope among university students. Uz Baş (2016) has assessed the "Positive Psychology" course according to comments and life satisfaction levels of counselor candidates. Findings showed that counselor candidates believe that the Positive Psychology course has contributed to their vocational and personal / social developments. In addition, the results have demonstrated that the Positive Psychology course is effective for increasing life satisfaction scores of counselor candidates.

\subsection{The Aim of the Study}

Purpose of this study is to assess the views and opinions of school principals and teachers on positive education. In achieving this goal, the study addresses five objectives: (1) to evaulate the views of school principal and teachers on Positive Education, (2) to evaulate the views of school principals and teachers on Positive Psychology, (3) to get school principals' and teachers'opinions about the role of schools in increasing students' well-being, (4) to get school principals' and teachers'opinions about teaching both academic skills and well-being skills in schools, and (5) to get school principals' and teachers'opinions about the needs of schools for positive education. School principals, teachers and school counselors as well as researchers who are interested in positive education may benefit from the findings of this study.

\section{Method}

\subsection{Research Design}

A qualitative descriptive research method is used to assess the views and opinions of school principals and teachers on positive education. The goal of qualitative descriptive studies is a comprehensive summarization of specific events experienced by individuals or groups of individuals (Lambert \& Lambert, 2012).

\subsection{Participants}

The sample of the study includes 8 school principals and 12 teachers who attend different public schools in Izmir, Turkey. Nine participants are from elementary schools, 6 participants are from middle schools, and 5 participants are from high schools. Participants' ages range between 32 to 51 years, 12 of them were male, and 8 of them were female. 


\subsection{Measures}

Data is collected through semi-structured interview technique. The interview protocols have been prepared by the researchers for the sole purpose of this study. Five open-ended questions have been asked to school principals and teachers. The researchers have chosen open-ended interviews since interviews have allowed participants to discuss their opinions, views and experiences fully in details. The following questions have been addressed: (1) What are school managers' and teachers' knowledge about Positive Education? (2) What are school principals' and teachers' knowledge about Positive Psychology? (3) What are school principals' and teachers' views about the role of schools in increasing students' well-being? (4) What do school principals and teachers think about teaching both academic skills and well-being skills in schools? (5) What do school principals and teachers think about the needs of schools for positive education? The demographic information including age, gender, profession and the schools where they work have also been obtained.

\subsection{Procedure}

The interviews with school principals and teachers have been conducted in their workplaces and have lasted in approximately 30 minutes. Before conducting the interviews, the participants have been informed about the purpose of the study and have been asked if they would be interested in participating to the study. Upon their consent, the researcher has scheduled a visit with the participant. The interviews have been audio-recorded. Also, during the interview, the researchers have taken notes.

\subsection{Data Analysis}

Qualitative data that have been collected from the open-ended questions' answers have been evaluated by the content method (Yıldırım \& Şimşek, 2005). In data analysis process, participants' answers have been labelled and coded by using the conceptual framework, and then categorized. The findings have been presented in tables. Also the answers of participants for the open-ended questions have been submitted by directly quotation method.

\section{Results}

Research findings are presented in order of sub-questions of the study. The first question of the interview aims to evaluate the views of school principals and teachers on Positive Education. Responses to this question are summarized in Table 1.

Table 1. The views of school principals and teachers on Positive Education

\begin{tabular}{llll}
\hline Themes & Categories & F & \% \\
\hline Contemporary & Student-centered education & 4 & 20 \\
education approach & Active learning & 3 & 15 \\
& Individuaized education in terms of students' concerns and needs & 3 & 15 \\
& Supporting student / Supporting teachers & 2 & 10 \\
& Entertainingly learning & 1 & 5 \\
& Democratic education & 1 & 5 \\
& Studensts' better expression themselves. & 1 & 5 \\
& & 7 & 35 \\
Positive school/Positive & Positive school & 5 & 25 \\
class & Equality of opportunity in education/positive discrimination & 5 & 25 \\
& Focusing to students' strengtens. & 3 & 15 \\
& Happy students & 2 & 10 \\
& Emphasis reward system in education & 1 & 5 \\
& Education which all shareholders of the school took pleasure & 4 & 20 \\
Other & & 2 & 10 \\
& Scientific education & 2 & 10 \\
\hline
\end{tabular}

The results show that 18 of the participants $(90 \%)$ have no knowledge of positive education, while only one participant $(5 \%)$ has a knowledge of positive education and the other one $(5 \%)$ has partial knowledge. They have been asked to share their opinions about this term. The answers have been categorized into three main themes: Contemporary education approach, Positive school/class, and other. Table 1 shows the detailed answers of the participants for each themes.

Some answers of participants for the views on positive education were presented below:

"Actually I have not got any idea. I think that it might be an education approach in which students and teachers would come to classroom willingly, students would learn by enjoying themselves and love school." (Participant number 5) 
"No, I do not know. Positive training concept evokes two things. First, education which would bring success to the forefront, not failure. I think it might be an education model which would make positive discrimination to disadvantaged groups (women, ethnic and religious minorities, disabled, etc.)" (Participant number 6)

"Yes, I know the following: The approach towards training teachers under the leadership of the school principal" (Participant number 14)

Table 2. The views of school principals and teachers on Positive Psychology

\begin{tabular}{llll}
\hline Themes & Categories & f & \% \\
\hline Positive approach & Focusing individuals' positive sense and feelings and support them. & 10 & 50 \\
& Supporting for adaptation to life and social relationships. & 3 & 15 \\
& Emphasising to self-development & 2 & 10 \\
& Very important & 1 & 5 \\
\multirow{3}{*}{ Other } & Preventive approach & 1 & 5 \\
& Solution oriented & 1 & 5 \\
& System theory & 1 & 5 \\
& The consept is meaningless & 1 & 5 \\
& I haven't got any guess. & 1 & 5 \\
\hline
\end{tabular}

The second question of the interview aims to to evaulate the views of school principals and teachers on positive psychology. Responses to this question are summarized in Table 2. The results show that 3 of the participants (15\%) have a knowledge of positive education, while 14 of them $(70 \%)$ have no knowledge of positive education and 3 of them $(15 \%)$ has partial knowledge. They have been asked to share their opinions about positice psychology. The answers have been categorized into two main themes: Positive approach, and other. The detailed answers of the participants for positive psychology are presented in Table 2.

Some answers of participants for the views on positive psychology are presented below:

"I have very little information. I know as an approach that focuses on the positive aspects of a person's psychology. For example an approach that makes you see the full side of the glass instead of the blank side." (Participant number 1)

"It's the first time I hear of this. I consider it as an psychology approach in which people wouldn't scare of psychology (as for many people psychology / psychiatry means ill health) on the other hand, psychology would help them with their self-actualization, emphasize on their being individuals and building a more positive relationship." (Participant number 2)

"No. I didn't remind me anything. It may be a new subfield of psychology." (Participant number 17)

Table 3. School principals' and teachers' opinions about the role of schools in increasing students' well-being

\begin{tabular}{|c|c|c|c|}
\hline Themes & Categories & $\mathbf{F}$ & $\%$ \\
\hline \multirow{3}{*}{$\begin{array}{l}\text { Schools can increase } \\
\text { students' well-being }\end{array}$} & It is enough to want & 4 & 20 \\
\hline & It is possible with short steps & 3 & 15 \\
\hline & It is possible by taking students' opinion & 2 & 10 \\
\hline \multirow{8}{*}{$\begin{array}{l}\text { Schools can increase } \\
\text { students' well-being, } \\
\text { but it depends on the } \\
\text { changes in current } \\
\text { conditions }\end{array}$} & It depends on awareness of teacher and administrators & 8 & 40 \\
\hline & It depends on the revision of central exam systems & 4 & 20 \\
\hline & $\begin{array}{l}\text { It depends on the improvement of physical and socio-cultural climate } \\
\text { of schools }\end{array}$ & 3 & 15 \\
\hline & $\begin{array}{l}\text { It is possible if education would be individualized or become } \\
\text { student-centered }\end{array}$ & 2 & 10 \\
\hline & It depends on radical changes in educational system & 2 & 10 \\
\hline & $\begin{array}{l}\text { It is possible if contemporary educational programs would be } \\
\text { developed }\end{array}$ & 2 & 10 \\
\hline & It is possible if schools would be integrated into society & 1 & 5 \\
\hline & $\begin{array}{l}\text { It is possible if education faculties would train teacher candidates } \\
\text { about positive education }\end{array}$ & 1 & 5 \\
\hline \multirow{6}{*}{$\begin{array}{l}\text { Schools cannot increase } \\
\text { students' well-being }\end{array}$} & Education system is failing & 2 & 10 \\
\hline & School's format is obstacle & 1 & 5 \\
\hline & Parents' pressure/expectation is obstacle & 1 & 5 \\
\hline & Curriculum is more academic oriented & 1 & 5 \\
\hline & Compulsory optional (!) courses & 1 & 5 \\
\hline & Ordinary classroom environment & 1 & 5 \\
\hline
\end{tabular}

The third question of the interview is addressed to get school principals' and teachers' opinions about the role of schools in increasing students' well-being. Responses to this question are summarized in Table 3. Most of the participants believe that schools can improve students' well-being. The answers are categorized into three main themes: Schools can 
increase students' well-being, schools can increase students' well-being, but it depends on the changes in current conditions, and schools cannot increase students' well-being. The detailed answers of the participants are presented in Table 3 .

Some answers of participants for the views on positive psychology were presented below:

"Two years ago in my school located in the countryside, I realized that our students didn't have social and sportive opportunities which their peers have in big cities and decided to start some social classes. In the few months of the course, as we didn't have someone else to do it, I volunteered to give guitar lessons. We only started these courses with bağlama and guitar but soon added ebru art, mind games, basketball, volleyball, gymnastics, art and robot design. It is the first time for a state school in Turkey to organize a summer course for two months with 100 participants. We witnessed great improvement in terms of both academic and social levels of our students after these courses. When they entered the gate in the morning they had smiling faces. My experience proves that school can increase their level of happiness." (Participant number 20)

"Both the class and the school must be appropriate. All employees at the school must be conscious about it. For example, when I ask the school principal to have lesson outside instead of classroom she should not interfere with it." (Participant number 5)

"School format is not appropriate for students' happiness. Teacher-learner relationship, students' being passive in learning, teaching-learning process which is against the nature of students and the fact that academic studies almost cover all the school day... all these factors make it impossible for students to be happy. We can also say that the expectations of parents adversely affect students." (Participant number 15)

The fourth question of the interview is addressed to get school principals' and teachers' opinions about teaching both academic skills and well-being skills in schools. Responses to this question are summarized in Table 4. Most of the participants believe that schools can teach both academic skills and well-being skills. The answers were categorized into three main themes: Positive outcomes, Conditions for positive education, and other. The detailed answers of the participants are presented in Table 4.

Table 4. School principals' and teachers' opinions about teaching both academic skills and well-being skills in schools

\begin{tabular}{|c|c|c|c|}
\hline Themes & Categories & $\mathbf{F}$ & $\%$ \\
\hline \multirow[t]{5}{*}{ Positive outcomes } & It contributes to personal development of students & 7 & 35 \\
\hline & It contributes to quality of education & 2 & 10 \\
\hline & It supports academic achievement of students & 2 & 10 \\
\hline & Students become happier & 2 & 10 \\
\hline & It contributes to future education & 1 & 5 \\
\hline \multirow[t]{8}{*}{$\begin{array}{l}\text { Conditions for positive } \\
\text { education }\end{array}$} & $\begin{array}{l}\text { Theachers and school principals shoul be trained about positive } \\
\text { education. }\end{array}$ & 6 & 30 \\
\hline & Radical changes in education system are necessary. & 3 & 15 \\
\hline & Physical infrastructure and environment of schools should be improved. & 2 & 10 \\
\hline & $\begin{array}{l}\text { Much more financial resource from government budget should be } \\
\text { provided. }\end{array}$ & 1 & 5 \\
\hline & Students' characteristics and talents should be considered. & 1 & 5 \\
\hline & $\begin{array}{l}\text { Cooperation between Ministry of National Eduction and universities } \\
\text { should be created. }\end{array}$ & 1 & 5 \\
\hline & Pilot schools and teams should be created. & 1 & 5 \\
\hline & Classroom sizes shoul be decreased. & 1 & 5 \\
\hline \multirow[t]{5}{*}{ Other } & It is not possible in current education system & 2 & 10 \\
\hline & It is necessary because of problems of current education system & 1 & 5 \\
\hline & $\begin{array}{l}\text { The topics which are included in positive education are already present } \\
\text { in our curriculum }\end{array}$ & 1 & 5 \\
\hline & Students' happiness is more important than academic success. & 1 & 5 \\
\hline & It is possible in current education system & 1 & 5 \\
\hline
\end{tabular}

Some answers of participants for the views on positive psychology are presented below:

"Of course it can be dealt together. If there is a success in the issues stipulated by the positive education, self-confidence of the students will develop. Consequently, this will affect academic success positively. Positive emotions contribute to the socialization of students. Developing their strengths will have positive impact on their academic success. By realizing their interests, they will go in this way. It will contribute to their future academic career. For them it will be easier to adapt to the rules of the society they live. All of these can be dealt with academic subjects." (Participant number 7) 
"Especially in primary schools, improving students' positive emotions is directly related to personality of the classroom teacher. It comes/ may come true in the classes of kind teachers who care about student happiness. However, I don't know whether ögretmen yüzdesinde bu fark anlaml midir. In our education system, as teacher success is directly associated with academic success, it is difficult to build awareness among teachers on this issue, at least in the short term. In fact there are enough hours students recognize and develop strong character (at least in the elementary school). Using this time appropriately is another matter of teachers." (Participant number 6)

"It is so difficult to apply this approach in the current educational system. The current system is completely based on test scores." (Participant number 16)

The last question of the interview aims to get school principals' and teachers' opinions about the needs of schools for positive education. Most of the participants believe that schools need to positive education applications. The answers are categorized into three main themes: Positive education is necessary because current education system is problematic, Positive education is necessary because it will produce positive outcomes, and there is no need for positive education. The detailed answers of the participants are presented in Table 5.

Table 5. School principals' and teachers' opinions about the needs of schools for positive education

\begin{tabular}{|c|c|c|c|}
\hline Themes & Categories & $\mathbf{F}$ & $\%$ \\
\hline 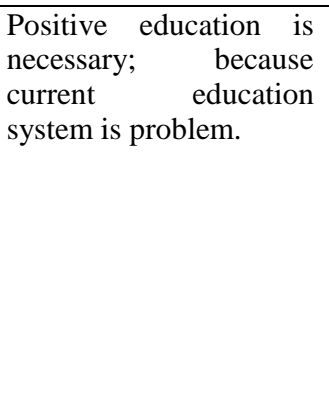 & $\begin{array}{l}\text { Teachers and especially students in schools are unhappy. } \\
\text { The schools are overemphasizing academic achievement } \\
\text { Infrastructure of schools is inadequate. } \\
\text { Teachers and school managers are not competent. } \\
\text { Students have got a lot of negative emotions and behaviors. } \\
\text { Schools cause atrophy their talants. } \\
\text { The system cannot train student who are creative, productive and } \\
\text { rogatory. } \\
\text { Students don't enjoy from learning. } \\
\text { Students cannot identify with school. } \\
\text { Students cannot develop identity. }\end{array}$ & $\begin{array}{l}11 \\
6 \\
3 \\
3 \\
3 \\
2 \\
2 \\
1 \\
1 \\
1\end{array}$ & $\begin{array}{l}55 \\
30 \\
15 \\
15 \\
15 \\
10 \\
10\end{array}$ \\
\hline $\begin{array}{l}\text { Positive education is } \\
\text { necessary; because it } \\
\text { will produce positive } \\
\text { outcomes }\end{array}$ & $\begin{array}{l}\text { Students experience positive emotions. } \\
\text { Students' academic success levels increase. } \\
\text { Positive thinking culture doesn't root in schools. } \\
\text { Students much more become socialized. }\end{array}$ & $\begin{array}{l}5 \\
2 \\
1 \\
1\end{array}$ & $\begin{array}{l}25 \\
10 \\
5 \\
5\end{array}$ \\
\hline $\begin{array}{l}\text { There is no need for } \\
\text { positive education }\end{array}$ & Positive education is a fashion. & 1 & 5 \\
\hline
\end{tabular}

Some answers of participants for the views on positive psychology are presented below:

"Current education system makes students and teachers unhappy. The system is too focused on academic achievement. Exams are primarily important. What kinds of questions are asked in the exam? Teachers give lessons depending on this. This is our state. . In addition, parents have intense pressure on academic achievement. Crowded classrooms are another problem. School administrators are not conscious." (Participant number 5)

"Considering that schools can meet the needs of the individuals more actively, it would be appropriate if schools used conception of positive education. For good / clear identification of the interests and abilities of the individual, the creation of a new project on how to develop the individual's interests and individuals'feeling more powerful I think such a conception is necessary." (Participant number 13)

"Nowadays "positive education" has become very popular. There is no need to invent something which has already been invented. I see this concept as a marketing effort. Positivity is already a feature that should be in every human being. Ask yourself: "Am I really positive?" By considering this, we should deal with the core, rather than fashion." (Participant number 8)

\section{Discussion}

The purpose of this study is to assess the views and opinions of school principals and teachers on positive education. The first two interview questions are about the knowledge of school principals and teachers about positive education and positive psychology. Findings reveal that a majority of the participants have no knowledge about positive education and positive psychology. This finding suggests that teachers and school principals need to be informed of positive education and positive psychology. Positive education is a new approach in the field of education. It emphasizes that schools should teach well-being skills along with academic skills (Seligman et al., 2009). Recently studies show that schools can teach well-being skills (Shoshani \& Sarit Steinmetz, 2013; Williams, 2011). In Turkey, no previous studies have investigated positive education interventions in schools. Recently, one book which addresses major concepts of 
positive education is published by Eriner-Tekinalp and Işık-Terzi (2016). On the other hand several studies have been conducted on positive psychology (e.g., Ergüner-Tekinalp, 2016; Eryllmaz, 2012). These studies which addressed positive psychology are usually conducted by the researchers in the field of counseling and psychology. We found only one study which has focused on positive psychology in educational administration (Aydın, Yılmaz \& Altınkurt, 2013).

In the current study, school principals and teachers have been asked what they think about the role of schools in increasing students' well-being. Many participants report that schools can increase students' well-being. They also declare that current education system and conditions should be revised in order to achieve this goal. They mention that in order to teach well-being skills at school, teacher and administrators should be aware of positive education interventions. They also state that central exam systems should be revised, physical and socio-cultural climate of schools should be improved, and so on.

The fourth question of the interview is about school principals' and teachers' opinions on teaching both academic skills and well-being skills in schools. The majority of the participants report that both academic and well-being skills can be taught at schools. They report that positive education lead to positive outcomes including greater happiness and academic success. On the other side, they reported that some educational arrangements should be implemented in order to achieve this goal. They mentioned that teachers and school principals should be trained about positive education, physical infrastructure and environment of schools should be improved, cooperation between Ministry of National Education and universities should be created, and so on. Indeed, training of the school personnel is a crucial factor for effectiveness of positive education interventions (Seligman et al., 2009).

The last question of the interview is about school principals' and teachers' opinions on the needs of schools for positive education. The majority of the participants report that positive education is necessary, because current education system is problematical. They state that teachers and especially students in schools are unhappy, and schools are overemphasizing academic achievement. The notions of participants about positive education at schools are consistent with the opinion of Seligman and his colleagues (2009) on positive education. They say that there is widespread depression and spotty increases in happiness among young people. They also indicate that schools have traditionally overemphasized academic achievement, and concluded that well-being should be taught in school.

Positive psychology movement has grown so quickly in recent years and positive psychology courses have sprung up in universities and high schools (Csikszentmihalyi, 2009; Gable \& Haidt, 2005). Recent research findings which are conducted in Turkey provide the evidence of the effectiveness of class-based well-being interventions among university students (Koydemir \& Kahraman, 2015; Uz Baş, 2016). On the other hand, there is no evidence to support to the effectiveness of teaching well-being skills at elementary or secondary schools. This study is an initial attempt to assess school principals' and teachers' opinions about integrating positive psychology into schools. The current findings support the notion that well-being skills should be taught in schools.

In summary, school principals and teachers need to be more aware of the importance of improving well-being of students at schools. Positive Psychology has a variety of application fields in the schools. Seligman and his colleagues (2009) suggest that schools are excellent location for well-being initiatives. Fredrickson (2001) suggested that educators need to transform schools into enabling institutions. It must be noted that school principals and teachers should be informed about the aim and scope of positive psychology and positive education. School counselors may also benefit from positive psychology interventions that aim to enhance well-being of students. They may coordinate school-wide activities for integrating well-being skills into education programs at schools. Positive psychology and positive education courses and/or subjects should be incorporated into the training programs of school principals.

Although the results of this study have contributed to the literature regarding positive education, limitations should be considered. The current study includes only 20 school principals and teachers from a Western city of Turkey. The future studies which include the different populations from different educational levels will be more beneficial for evaluating the opinions of the educators about positive education.

\section{References}

Aydın, A., Yılmaz, K., \& Altınkurt, Y. (2013). Positive psychology in educational administration. International Journal of Human Sciences, 10(1), 1470-1490.

Csikszentmihalyi, M. (2009). The Promise of Positive Psychology. Psychological Topics, 18(2), 203-211.

Dulagil, A., Green, S., \& Ahern, M. (2016). Evidence-based coaching to enhance senior students' wellbeing and academic striving. International Journal of Wellbeing, 6(3), doi: 131-149. doi:10.5502/ijw.v6i3.6

Ergüner-Tekinalp, B. (2016). Examination of Adlerian theory within the context of positive psychology. The Journal of Happiness \& Well-Being, 4(1), 34-49. 
Eryılmaz, A. (2013). Using of positive psychology on psychological counseling and guidance context on character strength and preventive services. The Journal of Happiness \& Well-Being, 1(1), 1-22.

Fredrickson, B. L. (2004). The broaden-and-build theory of positive emotions. Philosophical Transactions of the Royal Society of London B, Biological Sciences, 359, 1367-1378. https://doi.org/10.1098/rstb.2004.1512

Gable, S. J., \& Haidt, J. (2005). What (and why) is positive psychology? Review of General Psychology, 9(2), 103-110. https://doi.org/10.1037/1089-2680.9.2.103

Green, L. S. (2014). Positive Education: An Australian Perspective. In Furlong, Gilman \& Huebner (Eds.), Handbook of Positive Psychology in Schools, 2nd Edition.

Koydemir, S., \& Kahraman, H. (October 2015). Happiness on campus: The effects of an undergraduate wellbeing course on the wellbeing of students. 13th National Congress of Counseling and Guidance, Mersin, Turkey.

Lambert, V. A., \& Lambert, C. E. L. (2012). Editorial: Qualitative Descriptive Research: An Acceptable Design.

Noble, T., \& McGrath, H. (2008). The positive educational practices framework: A tool for facilitating the work of educational psychologists in promoting pupil wellbeing. Educational \& Child Psychology, 25(2), 119-134.

Noble, T., \& McGrath, H. (2015). PROSPER: A New Framework for Positive Education. Psych. Well-Being, 5, 2-17. https://doi.org/10.1186/s13612-015-0030-2

Norrish, J. M., Williams, P., O’Connor, M., \& Robinson, J. (2013). An applied framework for positive education. International Journal of Wellbeing, 3(2), 147-161. doi:10.5502/ijw.v3i2.2

Reschly, A. L., Huebner, E. S., Appleton, J. J., \& Antaramian, S. (2008). Engagement as flourishing: The contribution of positive emotions and coping to adolescents' engagement at school and with learning. Psychology in the Schools, 45(5), 419-431. https://doi.org/10.1002/pits.20306

Seligman, M. E. P., Ernst, R. M., Gillham, J., Reivich, K., \& Linkins, M. (2009). Positive education: positive psychology and classroom interventions. Oxford Review of Education, 35(3), 293-311. https://doi.org/10.1080/03054980902934563

Shoshani, A., \& Steinmetz, S. (2013). Positive Psychology at School: A School-Based Intervention to Promote Adolescents' Mental Health and Well-Being. Journal of Happiness Studies. https://doi.org/10.1007/s10902-013-9476-1

Terjesen, M. D., Jacofsky, M., Froh, J., \& Digiuseppe, R. (2004). Integrating positive psychology into schools: Implications for Practice. Psychology in the Schools, 41(1), 163-172. https://doi.org/10.1002/pits.10148

Eriner-Tekinalp, B., \& Işık-Terzi, Ş. (Eds.) (2016). Positive Psychology Applications in Education (in Turkish). Ankara: Pegem Publishers.

Uz, B. A. (2016). Assessment of Positive Psychology Course according to comments and life satisfaction levels of psychological counselor candidates. Journal of Education and Training Studies, 4(3), 1-8. https://doi.org/10.11114/jets.v4i3.1195

Waters, L. (2011). A review of school-based positive psychology interventions. The Australian Educational and Developmental Psychologist, 28(2), 75-90. https://doi.org/10.1375/aedp.28.2.75

Williams, P. (2011). Pathways to positive education at Geelong Grammar School. Integrating positive psychology and appreciative inquiry. AI Practitioner, 13(2), 8-13.

Yıldırım, A., \& Şimşek, H. (2005). Research Methods in Social Sciences (in Turkish). Ankara: Seçkin Publishers.

\section{Copyrights}

Copyright for this article is retained by the author(s), with first publication rights granted to the journal.

This is an open-access article distributed under the terms and conditions of the Creative Commons Attribution license which permits unrestricted use, distribution, and reproduction in any medium, provided the original work is properly cited. 